\title{
Heading and Leading Educational Institutions in Rural Africa: A Western Trained Educationists Experiences in Ghana
}

\section{William Otu ${ }^{1}$}

${ }^{1}$ Methodist University College, Dansoman-Accra, Ghana

\begin{abstract}
The observation and experiential study talks about the demanding role of institutional heads and leaders in Africa; taking into consideration the culture and norms of governance in rural traditional Africa. The study also took a look at the traditional leadership in Africa, its leadership style, and its influence on its local societies and communities. Case study was used to illustrate the study.
\end{abstract}

Keywords: Leadership, Traditional, Behaviours, Group goals and responsibilities, Achievement.

\section{Contents}

1. Introduction ............................100

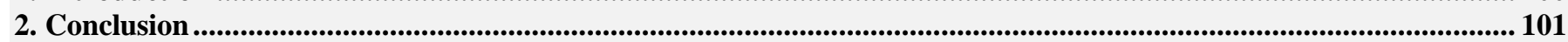

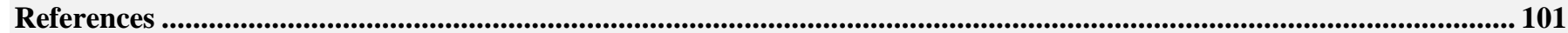

Citation | William Otu (2016). Heading and Leading Educational Institutions in Rural Africa: A Western Trained Educationists Experiences in Ghana.
$\begin{array}{ll}\text { Asian Journal of Social Sciences and Management Studies, 3(2): 99-101. } \\ \text { DOI: } & 10.20448 / \text { journal.500/2016.3.2/500.2.99.101 } \\ \text { ISSN(E) : } & 2313-7401 \\ \text { ISSN(P): } & 2518-0096 \\ \text { Licensed: } & \text { This work is licensed under a Creative Commons Attribution 3.0 License } \\ \text { Funding: } & \text { This study received no specific financial support. } \\ \text { Competing Interests: } & \text { The author declares that there are no conflicts of interests regarding the publication of this paper. } \\ \text { Transparency: } & \text { The author confirms that the manuscript is an honest, accurate, and transparent account of the study was reported; that no } \\ & \text { vital features of the study have been omitted; and that any discrepancies from the study as planned have been explained. } \\ \text { Ethical: } & \text { This study follows all ethical practices during writing. } \\ \text { History: } & \text { Received: 20 August 2015/ Revised: } 16 \text { October 2015/ Accepted: } 2 \text { November 2015/ Published: } 16 \text { November } 2015 \\ \text { Publisher: } & \text { Asian Online Journal Publishing Group }\end{array}$




\section{Introduction}

What is leadership? There are various schools of thoughts to the definition of leadership but for the purpose of this write up, the following definitions will be considered. Leadership refers to the use of a person's abilities and talents to influence others in the achievement of a common goal. Stoner and Wankel (1986) define leadership as the process of directing and influencing the task-related activities of group members. Another definition is that, leadership is the process of organized group towards goal setting and goal achievement. Again, leadership is explained as the ability to persuade others to seek defines objectives enthusiastically. It is important to note that, it is the human factor which binds a group together and motivates it towards a goal achievement. It is again important to note that, leadership implies influence. So the idea of influence is central to leadership.

Leadership implies that, there are followers because no one can claim to be a leader when there are no followers. Again, leadership is goal directed, so whenever there is a leader, there must be a goal, objective or task to mind. In addition, Leadership includes the ability to motivate one's followers. The able leader must be able to inspire his or her personnel to put in their best.

\subsection{Traditional Rural African Leadership}

In the traditional African rural societies, the leader who was often the chief and his elders, featured prominently in educational, social and economic life of the people in his or community.

According Archer (2003) in most African rural communities, societies as well as 'peri-urban' societies, the chiefs are chosen among the members of the royal family as to how they became royal families nobody knows. The type of leadership was however not uniform because they were different 'political system

\subsection{Traditional Leadership Style in Africa}

Early anthropologist distinguished two main types of political 'systems'. The centralised authority: example; 'The Ashantis' of West Africa and the Zulus' of South Africa'. The other type lacked centralised authority: example; The Akuapem of Eastern Ghana in West Africa and the Nuer of Sourthern Sudan'

The centralised system is the most predominant political system with very strong political as well as military system. The Ashanti Kingdom for example has a very complex set up. It is made up of the king (The equivalent of the head of a state), immediately followed by a group of highly powered chief called 'Omahene' (Thus, equivalent of a gorvernor of a state). These are in charge of a whole tribe which is states in themselves. Under each 'Omahene' were the various 'chiefs' who were the leaders of the big towns comparable to a municipal or county 'chief executive'.

The chiefs were responsible to the 'omahene' and the 'Omahene' to the king-Asantehene'. In each cae or those levels, the powers of the leader (chief, omahene and the king) are great, even absolute. This is so because the three branches of power distinguished by public law-legislative, executive and judiciary are held as a unit by the sovereign.

The monarch was sacred-in a deeper sense than the power of the Western monarchies or that of Asian monarchies based on divine right. The sovereign by virtue of his or her office, had a special position in the world of vital forces. He or she shared in them more than the ordinary people, for he or she represented his or her people identified with them; 'a mystical sense; he or she was his or her community. Due to this awe surrounding his or her position, there is a strict protocol surrounding him or her which indicates that the leadership is set apart from other men. Sometimes special vocabulary is used to describe his or her ordinary activities such as drinking, eating, sleeping and even his or death.

Access to him or her is through intermediaries' and a strict protocol. He or she was not to be seen out on ordinary days.

The governmental instruments were the court, which is made up of his/her trusted and devoted friends, relatives and allies who represents the lineages close to him or her. The monarchs, though absolute is expected to respect established right to uphold justice and to behave with kindness in rewarding the deserving.

The obedience of his or her subjects was the counterpart of his or her leadership. An agreeable manner seemed to have been valued as much as material liberality; an arrogant chief rapidly lost his or her followers. In return for his or her protection and leadership he or she have claims to the service of his or people. They had to pay taxes to him or her in case and in kind. Craft men supply their wares freely to him or her; traders and all other producers gave part of their product to him or her subjects serve him or her in public works, helps in building, weeding and cleaning roads. He or She lavish gift and honours on those who has distinguish themselves in wars and other public services.

According to Annor (2003) the leader be it the Chief, Omahene, and the King provide for the needy. The way he or she gets people to do what is expected of them is through collective pressures, ridicules, isolation and ostracising. The traditional African leader was authoritarian with more or less absolute powers. He or she was for removed from his or her subjects and they look upon him or her with great amount of respect. He or she has the right to demand special services from his or her 'subjects' but he or she also sees to the welfare of his or her people. $\mathrm{He}$ or she shows personal interest in the individual and make sure that as far as possible, the needs of every individual is met. Usually his or her subjects present gifts to him or her. These gifts usually win the givers favour before the king. A leadership with these characteristics makes it difficult for indigenous African to behave under type of leadership which is personal, democratic and less concerned with personal needs of the individual.

\subsection{Case Study 1}

There was a teacher in a rural community that a western trained professional teacher headed. The teacher usually goes to school drunk; he is not punctual and time conscious. After several queries handed to him by the head of the school, the teacher did not heed to the warning to refrain from his unacceptable behaviour. Several consultations were done to ensure that this teacher tends a new leave in order to deliver well as a teacher. He was 
given a sack. Then came the traditional leadership in a rural setting behaviours; the local chief together with his elders summon the head and his staff before the chief to answer to why his 'kin' has been sacked, after the narration and evident submitted to the local chief indicating the queries given to him and his elders who are also witnesses to the behaviours of the said teacher, demanded the re-instatement of the teacher because he is 'kin' and a royal.

The educational authorities to the outmost surprise of the head was given a transfer letter to the head stating among things the demand of the rural folks, elders and the chief that they can live with the head because he is not cooperative.

It can be observed here that little regard is given to a well-structured institutional systems that woks with it rules and regulations and aims at achieving a specific goal. The effort of the head of the institution is therefore scarified for the whims and caprices of the chiefs and the traditional leaders of the communities. The educational authorities on the other hand expect that, the head of the institution adjust to the customs and the norms of the community without necessarily achieving the set educational target and goals of the nation.

\subsection{Case Study 2}

Parents demand of school authority for their wards to attend to domestic activities like farming and fishing one's in a week and also allowed to go to market every Friday morning before attending school.

The school head in this instance has no choice but to agree to the request of the community or the society to ensure that the school continue to exist. This demand is not done in a vacuum. It is done with the explicit knowledge of the local chief and the elders who are ward are also students in the schools. To them, societal good cannot be scarified for individual good like acquiring academic knowledge that may not benefit the society. Again it can be deduce that institution that looks like taking the power of the local chiefs and the elders from their hand is a treat to their leadership and are therefore not given the needed cooperation. The act therefore places a greater responsibility on the school head to draw a time table and sometimes re-structure a national curricular to be able to continue its work in a traditional rural community.

\section{Conclusion}

Leadership can be looked at from various perspective, but it practices differ from one geographical setting to the other. Even within the same geographical setting it practices in rural Africa demands a quick fit decision making skills in order to remain relevant. The western trained educationalist can therefore not holistically practice effectively without learning some few domestic leadership skills in traditional rural Africa before becoming relevant to the teaching profession.

\section{References}

Annor, K., 2003. Making education relevant to our societies. Takoradi-Ghana: Jacobus Publicationas.

Archer, F.K., 2003. Work and organisational practices in Africa 1. Biraa Publishers-Kumsi, 1(1): 32-33.

Stoner, J.A.F. and C. Wankel, 1986. Management. 3rd Edn., New Jersey: Prentice-Hall. 